\title{
Species distribution of ulcerative lesions on finfish in the Tar-Pamlico River Estuary, North Carolina
}

\author{
Jay F. Levine ${ }^{1}$, Jess H. Hawkins ${ }^{3}$, Michael J. Dykstra ${ }^{1}$, Edward J. Noga ${ }^{2}$, \\ David W. Moye ${ }^{3}$, R. Scott Cone ${ }^{1}$ \\ ${ }^{1}$ Department of Microbiology Pathology and Parasitology, College of Veterinary Medicine, 4700 Hillsborough Street, North \\ Carolina State University, Raleigh, North Carolina 27606, USA \\ ${ }^{2}$ Department of Companion Animal and Special Species Medicine, College of Veterinary Medicine, North Carolina State \\ University, Raleigh, North Carolina 27606, USA \\ ${ }^{3}$ Division of Marine Fisheries, Department of Environment, Health and Natural Resources, Washington, North Carolina 27889,
}

USA

\begin{abstract}
An estuarine survey was conducted between May 1985 and April 1987 to determine the occurrence of ulcerative lesions on finfishes in the Tar-Pamlico River Estuary, North Carolina. Fish were collected by pound net and trawls; with more than 70000 specimens obtained. Thirty-one species of estuarine fish were collected in the pound nets; Atlantic menhaden Brevoortia tyrannus represented $>$ $90 \%$ of the total catch. Forty-four species were collected in the trawls; spot Leiostomus xanthurus, Atlantic croaker Micropogonias undulatus, and Atlantic menhaden were the most frequently collected species. Menhaden was the predominant species affected with ulcerative lesions in both the pound net and trawl samples.
\end{abstract}

\section{INTRODUCTION}

Ulcerative disease syndrome (UDS) is a general term that has been used to describe a group of recently reported cutaneous diseases on finfishes (Hargis 1985). Superficial to deep ulcers, which at times extend into the peritoneal cavity and adjacent organs, have been described in a variety of species and age-classes of estuarine fish along the eastern seaboard (Dykstra et al. 1986, Noga \& Dykstra 1986). Cutaneous ulcers on fish are not a new problem, but the species distribution and occurrence of the syndrome is apparently expanding, and these lesions are now considered a regional problem (Dykstra et al. 1989).

Various agents have been suggested as determinants of these ulcerative diseases. Fungi such as Saprolegia sp. and Aphanomyces sp. have been associated with ulcerative mycosis (UM), a granulomatous infection affecting Atlantic menhaden in North Carolina and Virginia (Dykstra et al. 1986, Noga \& Dykstra 1986). Broad, sparsely branching fungal hyphae, similar to those associated with UM, and various bacteria have also been observed in Atlantic menhaden and weakfish Cynoscion regalis, in the St. Johns River, Florida (Te Strake \& Lim 1987; Dykstra et al. 1989). Although the variety of isolated agents suggests that some of these diseases are unrelated, these agents are generally opportunistic pathogens. Undetermined factors apparently compromise host defenses, making fish more susceptible to infection. This syndrome of ulcerative diseases may represent a biologic marker of the potentially larger problem of environmental degradation (Hargis 1985, Noga \& Dykstra 1986, Ahrenholz et al. 1987). However, the role of these agents as pathogens, and the manner in which pollutants may predispose fish to infection with these agents await confirmation.

Atlantic menhaden, weakfish, southern flounder Paralichthys lethostigma, American eels Anguilla rostrata, spot, and Atlantic croaker have all been found with ulcerative lesions (Hargis 1985, Noga \& Dykstra 1986, Te Strake \& Lim 1987). However, the potential effects of these cutaneous disorders on the stocks of these fish are unknown and might not be fully appreciated for years. Accordingly, an estuarine monitoring program was established in the spring of 1985, to determine the occurrence of these maladies in the TarPamlico River Estuary. Fish were collected by trawling and from pound nets to determine the species distribution of ulcerative lesions on finfishes in the estuary. 


\section{MATERIALS AND METHODS}

Fish were sampled in the Tar-Pamlico River Estuary from May 1985 through April 1987. Two methods of sampling were used, pound nets and trawls.

Pound nets. Four pound nets were sampled in the midsection of the river at. Bayview (latitude $76^{\circ} 47^{\prime} 47^{\prime \prime}$, longtitude $\left.35^{\circ} 26^{\prime} 01^{\prime \prime}\right)$; Durham Creek (Lat $76^{\circ} 49^{\prime} 01^{\prime \prime}$, Long $35^{\circ} 23^{\prime} 43^{\prime \prime}$ ); Lee Creek (Lat $76^{\circ} 46^{\prime} 58^{\prime \prime}$, Long $35^{\circ} 23^{\prime} 39^{\prime \prime}$ ); and Gaylord Bay (Lat $76^{\circ} 45^{\prime} 00^{\prime \prime}$, Long $35^{\circ} 25^{\prime} 15^{\prime \prime}$ ) (Fig. 1). The nets had a lead length of $c a$ $275 \mathrm{~m}$, set perpendicular to the shore, that led into a $32 \mathrm{~m}$ diam. pound. Nets were constructed of Size 36 twine with a $6.4 \mathrm{crn}$ stretched mesh, which retained most estuarine species greater than $70 \mathrm{~mm}$ forklength (FL).

Nets were sampled every $2 \mathrm{wk}$, as weather permitted, using a $24 \mathrm{~h}$ net set. Because fish tend to stratify in the net as it is pulled tight, a subsample of fish was obtained from the top, middle, and bottom of the net. These subsamples were combined for examination.

Trawls. Trawl stations were selected by partitioning the estuary into $300 \times 0.8 \mathrm{~km}^{2}$ grids, and randomly choosing individual grids for sampling. Adjacent grids, and those including non-navigable sections, were excluded from the survey. The sampling sites selected included a variety of bottom strata and represented a varied cross-section of habitats.

Monthly trawling was initially conducted between May 1985 and March 1986 at 24 stations located between the middle of Blount's Bay and Pamlico Point (Fig. 1). Drought conditions in the spring of 1986 substantially increased salinities and altered salinity gradients in the estuary. Accordingly, the sampling regime was altered to compensate for the movement of estuarine fish into the upper part of the system. Both the number and location of sampling grids were changed. In April 1986, new sampling grids were randomly added, but due to labor constraints, the number of stations was reduced from 24 to 18 . These stations covered the area from Washington to Gaylord Bay, North Carolina (Fig. 1).

During the first 11 mo of the survey, trawling was conducted in daylight. Nocturnal sampling was adopted between March 1986 and April 1987 to increase the number of specimens collected, and to improve our ability to accurately assess the prevalence of ulcerative lesions. Although various trawls were used during the first 2 mo of the study a $6.1 \mathrm{~m}$ threeseam net that fished $2.7 \mathrm{~m}$ of the water column was used between July 1985 and April 1987.

Examination of specimens. All specimens collected in pound net and trawl samples were examined for lesions. The weight $(\mathrm{g})$ and $\mathrm{FL}(\mathrm{mm})$ of initially 100 (May to October 1985) then 30 to 50 randomly selected individuals of each species in the pound net and trawl samples was recorded.

Ulcerative lesions were examined for fungi characteristic of UM in menhaden (Fig. 2). Lesions were examined either immediately after capture, after storage on ice, or after freezing. Freezing did not affect the ability to detect fungal hyphae in lesions. The surface and underlying musculature of lesions were scraped with a scalpel. Exudate and tissue removed from wounds were spread in a drop of water on a glass slide, stained with lactolphenol cotton blue, covered with a cover glass, and examined by light microscopy.

\section{RESULTS}

\section{Pound nets}

More than 19000 fish, representing 31 species, were collected in pound nets (Table 1). Seven species accounted for $>95 \%$ of the total catch. Atlantic menhaden was the most abundant species collected, and accounted for $>90 \%$ of the fish sampled. The

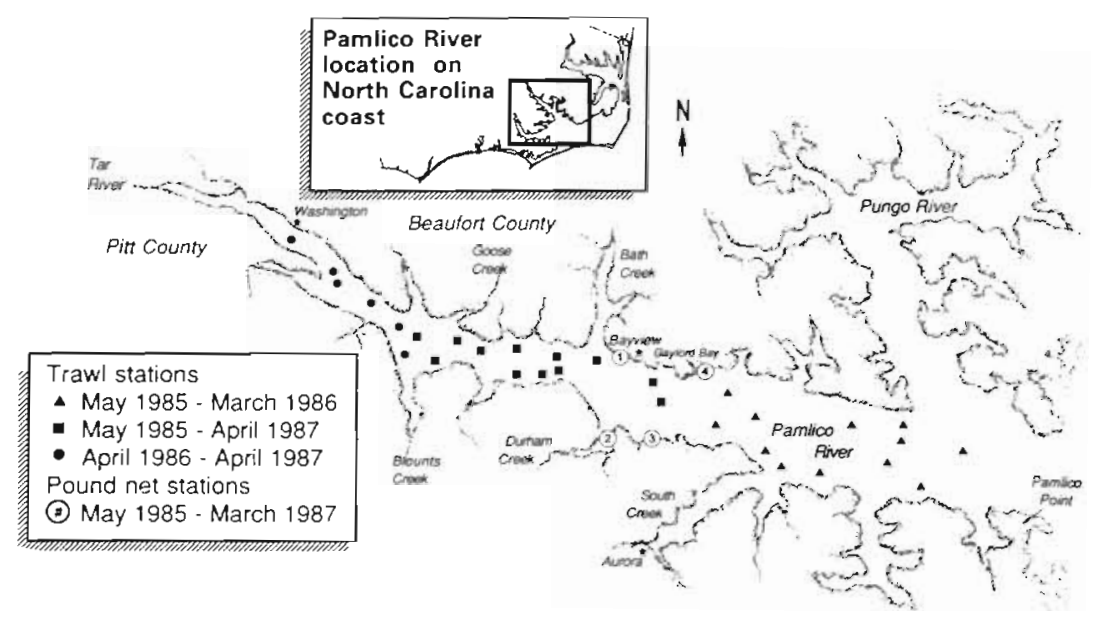

Fig. 1. Trawl stations and pound net sites in the Tar-Pamlico River Estuary 


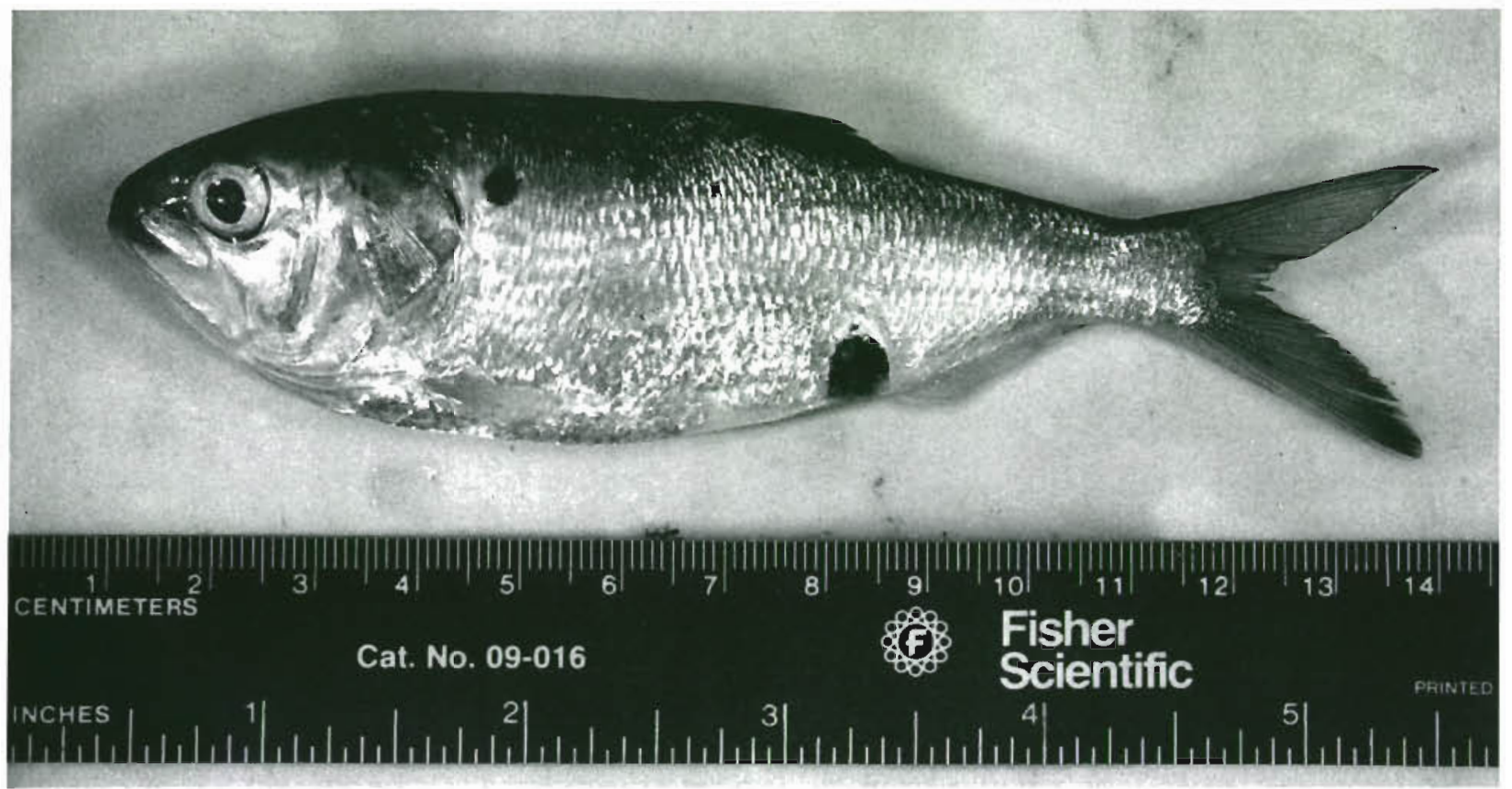

Fig. 2. Brevoortia tyrannus. Atlantic menhaden affected with ulcerative mycosis

Table 1. Species distribution of ulcerative lesions on fish collected in pound nets between May 1985 and April 1987 in the Tar-Pamlico River Estuary

\begin{tabular}{|c|c|c|c|c|c|c|}
\hline Species & $\mathrm{N}$ & Fish $(\%)$ & Lesions (no.) & Lesions $(\%)$ & Fungi (no.) & $\begin{array}{l}\text { Lesions } \\
\text { with fungi }(\%)\end{array}$ \\
\hline Bairdiella chrysoura & 130 & 0.7 & 1 & 0.8 & 1 & 100.0 \\
\hline Brevoortia tyrannus & 18261 & 92.8 & 303 & 1.7 & 244 & 80.5 \\
\hline Cynoscion regalis & 93 & 0.5 & 1 & 1.1 & 1 & 100.0 \\
\hline Dorosoma cepedianum & 244 & 1.2 & 2 & 0.8 & 0 & 0.0 \\
\hline Leiostomus xanthurus & 634 & 3.2 & 0 & 0.0 & 0 & - \\
\hline Micropogonias undulatus & 95 & 0.5 & 0 & 0.0 & 0 & - \\
\hline Paralichthys lethiostigma & 10 & $<0.1$ & 0 & 0.0 & 0 & - \\
\hline Other (24 species) & 216 & 1.1 & 0 & 0.0 & 0 & - \\
\hline Totals & 19683 & 100 & 307 & - & 246 & - \\
\hline
\end{tabular}

species composition and length frequency of fish sampled in each net was similar. Most of the fish examined were young-of-the-year (YOY) individuals.

Lesions were observed on 3 species (menhaden, weakfish, and silver perch Bairdiella chrysoura) collected in pound net samples (Table 1). Fungal hyphae were usually present in lesions but ulcerative lesions without evidence of fungal hyphae were also observed on affected fishes. However, because no histopathologic evaluation was performed on our specimens, fungal hyphae in some of the lesions may have been overlooked.

\section{Trawl survey}

More than 51000 fish, representing 44 species, were collected by trawling and examined for lesions (Table 2). Spot, Atlantic croaker, and Atlantic menhaden were the 3 most frequently collected species. The fish ranged from 31 to $201 \mathrm{~mm}$ in FL and, based on their length, were predominately YOY.

Atlantic menhaden was the most frequently affected species (Table 2). Although lesions were found on other species, they were uncommon, affecting $<2 \%$ of the fish sampled. 
Table 2. Species distribution of ulcerative lesions on fish collected in trawls between May 1985 and April 1987 in the Tar-Pamlico River Estuary

\begin{tabular}{|c|c|c|c|c|c|c|}
\hline Species & $N$ & Fish $(\%)$ & Lesions (no.) & Lesions $(\%)$ & Fungi (no.) & $\begin{array}{l}\text { Lesions } \\
\text { with fungi }(\%)\end{array}$ \\
\hline Bairdiella chrysoura & 496 & 0.9 & 6 & 1.2 & 4 & 66.6 \\
\hline Brevoortia tyrannus & 6286 & 12.0 & 940 & 15.0 & 771 & $91.2^{\mathrm{d}}$ \\
\hline Cynoscion regalis & 154 & 0.3 & 1 & 0.7 & 0 & 0.0 \\
\hline Dorosoma cepedianum & 520 & 1.0 & 3 & 0.6 & 0 & 0.0 \\
\hline Leiostomus xanthurus & 25366 & 48.2 & 29 & 0.1 & 7 & 24.1 \\
\hline Micropogonias undulatus & 17196 & 32.7 & 28 & 0.2 & 13 & 46.4 \\
\hline Paralichthys lethiostigma & 1308 & 2.5 & 3 & 0.2 & 1 & 33.3 \\
\hline Other (37 species) & 1266 & 2.4 & 1 & $<0.1$ & 1 & 100.0 \\
\hline Totals & 52592 & 100 & 1011 & - & 797 & - \\
\hline
\end{tabular}

\section{DISCUSSION}

During this study, ulcerative lesions were periodically epidemic on Atlantic menhaden in the TarPamlico River Estuary. Although lesions were markedly less common on other species, ulcers were also observed on silver perch, weak fish, spot, Atlantic croaker, and Southern flounder. The majority of these estuarine species are oceanic (in contrast to estuarine) spawners whose young utilize North Carolina estuaries as nursery areas (Ross \& Epperly 1985).

The presence of Oomycete hyphae and associated granulomas within lesions has been recognized as the hallmark of UM in Atlantic menhaden (Noga \& Dykstra 1986). Although grossly similar, UM-like lesions were observed on a variety of other fish species - some of those ulcers contained fungal hyphae of uncertain taxonomic placement and undetermined morphology. The lesions may have represented the end point of a distinctly different chain of events than those characterizing UM, or a parallel disease process. Atlantic menhaden, however, apparently possess a specific morphological, physiological, or behavorial risk factor(s) that makes them more susceptible to fungal invasion than other species of fish in the estuary.

Ulcerative mycosis is one of many cutaneous diseases that occur in estuarine species (Sinderman 1988). These diseases traditionally have been grouped colloquially under the term 'red sore' disease and, more recently, UDS (Hargis 1985). However, the use of general terms such as these, which are based on visual observations, may result in the erroneous recording of different disease processes as the same clinical entity. Distinction between these processes, however, is as complex as the systems in which they occur. Indeed, in this survey, we examined lesions microscopically for the broad, sparsely branching, aseptate hyphae characteristic of the Oomycetes associated with UM. Similar fungal hyphae were consistently found in scrapings obtained from lesions on Atlantic menhaden, but these hyphae may have represented more than one species of fungus. Two different genera of fungi have been isolated from Atlantic menhaden with UM (Dykstra et al. 1986), however, they cannot be easily distinguished in the field because identification requires that they be cultured. These fungi are ubiquitous opportunists, and possibly invade fish after some other agent has either altered the integrity of the skin, or systemically affected the immune system (Srivastaua 1980). Different agents may possibly predispose fish to different fungi, or initiate markedly different causal pathways that result in the same clinical entity. Specific diagnostic procedures integrating the expertise of various disciplines will be needed to accurately describe the natural history of these apparently new cutaneous diseases of finfishes.

UDS and various other recently described diseases of finfishes (e.g. 'fin rot' and hepatic adenocarcinoma in winter flounder and English sole) have been referred to as possible biological indicators of the degradation of our estuarine ecosystems (Muchelano \& Ziskowski 1976, Minchew \& Yarbrough 1977, Noga \& Dykstra 1986). Pollutants may play a role as potentiators of some of these problems, possibly altering the immune system or integument in a manner that makes fish susceptible to infection. These apparently new diseases, however, may represent an entirely natural phenomenon, or a complex causal synergism of abiotic and biotic factors.

The Atlantic menhaden fishery ranks first, in the North Carolina commercial fisheries, in total tonnage and commercial value. In addition, North Carolina estuaries are an important source of recruitment for the entire mid-Atlantic menhaden fishery Although UM 
has been associated with mortality in Atlantic menhaden, the actual impact of the disease on the menhaden fishery may not be fully appreciated for years. If the disease is pollution-related, recognition of the specific risk factors and pollutants associated with infection would facilitate efforts to control the influx of these materials into the Tar-Pamlico River Estuary and assist in reducing the impact of the problem on the Atlantic menhaden fishery.

Acknowledgements. Funds supporting this research were provided by the Water Resources Research Institute of the University of North Carolina and the Division of Marine Fisheries, North Carolina Department of Environment, Health and Natural Resources.

\section{LITERATURE CITED}

Ahrenholz, D. W., Guthrie, J. F., Clayton, R. M. (1987). Observations of ulcerative mycosis infections on Atlantic menhaden (Brevoortia tyrannus). NOAA natn. mar. Fish. Serv. tech. Memo U.S. Dep. Commerce SEFC-196, p. 1-10

Dykstra, M. J, Levine, J. F., Noga, E. J., Hawkins, J. H., Gerdes, P., Hargis, W. J., Grier, H. J., Te Strake, D. (1989). Ulcerative mycosis: a serious menhaden disease of the South-eastern coastal fisheries of the United States. J. Fish Dis. 12: 175-178

Dykstra, M. J., Noga, E. J., Levine, J. F., Moye, D. W., Haw-

Responsible Subject Editor: Dr T Evelyn, Nanaimo, B. C., Canada kins, J. H. (1986). Characterization of the Aphanomyces species involved with ulcerative mycosis (UM) in menhaden. Mycologia 78: 664-672

Hargis, W. J. (1985). Quantitative effects of marine diseases on fish and shellfish populations. Trans. N. Am. Wildl. Natur Res. Conf. p. 608-640

Minchew, C. D., Yarbrough, J. D. (1977). The occurrence of fin rot in mullet (Mugil cephalus) associated with crude oil contamination of an estuarine pond ecosystem. J. Fish Biol. 10: $319-323$

Muchelano, R. A., Ziskowski, J. (1976). Fin rot disease studies in the New York bight. Am. Soc. Limnol. Oceanog., Spec. Symp. 2: 329-336

Noga, E. J., Dykstra, M. J. (1986). Oomycete fungi associated with Ulcerative Mycosis in menhaden, Brevoortia tyrannus (Latrobe). J. Fish Dis. 9: 47-53

Ross, S. W. Epperly, S. P. (1985). Utilization of shallow estuarine nursery areas by fishes in Pamlico Sound and adjacent tributaries, North Carolina. In: Yancy-Aramcibia (ed.) Fish community ecology in estuaries and coastal lagoons: towards an ecosystem integration. UNAM Press, Mexico, p. 207-232

Sinderman, C. J. (1988). Epizootic ulcerative syndromes in coastal/estuarine fish. Albermale Pamlico estuarine study. Workshop on fishery diseases. Sept. 1987 Raleigh, North Carolina, p. 53-60

Srivastaua, R. C. (1980). Studies in fish mycopathology. A review. Part II. Mykosen 23: 390-391

Te Strake, D., Lim, D. V. (1987). Bacterial and fungal studies of ulcerative fish in the St. Johns River. Florida Dept. Environ. Reg. Contract Report WM 138

Manuscript first received: May 1, 1989

Revised version accepted: October 2, 1989 